${ }^{1}$ Programa de Pós-graduação em Ecologia e Evolução, Laboratório de Genética e Biodiversidade, Instituto de Ciências Biológicas, Universidade Federal de Goiás, Goiânia Goiás, Brazil; ${ }^{2}$ Laboratório de Anatomia Comparativa de Vertebrados, Departamento de Ciências Fisiológicas, Instituto de Ciências Biológicas, Universidade de Brasília, Brasília Distrito Federal, Brazil; ${ }^{3}$ Laboratório de Herpetologia e Comportamento Animal, Departamento de Ecologia, Instituto de Ciências Biológicas, Universidade Federal de Goiás, Goiânia Goiás, Brazil

\title{
Internal larval characters in anuran systematic studies: a phylogenetic hypothesis for Leptodactylus (Anura, Leptodactylidae)
}

\author{
Núbia Esther de Oliveira Miranda ${ }^{1,2}$, Natan Medeiros Maciel ${ }^{1,3}$, Karla Pêssoa Tepedino ${ }^{2}$ and Antonio Sebben $^{2}$
}

\begin{abstract}
There are few systematic studies based on internal buccal and larval cranium morphology of anuran tadpoles. Here we hypothesized phylogenetic relationships of frogs of the Leptodactylus genus with 84 internal larval characters, where 63 of them were described for the first time. We recovered Leptodactylus as monophyletic with two major clades. A similar topological arrangement was found by combining the larval with 98 adult morphology characters. PBS analysis revealed that the two data sets contributed differentially to establish major clades of Leptodactylus in the overall tree. This result was corroborated by the IDL test, which also indicated incongruences between data sets. Together with an overview of internal larval descriptions and discussions about the performance of these characters to reconstruct the phylogeny of Leptodactylus (i.e. homologies and homoplasies), we also provided information regarding intraspecific and populational variation found among the morphologies of the tadpoles sampled.
\end{abstract}

Key words: Leptodactylus - buccal morphology - larval cranial - phylogeny

\section{Introduction}

The application of larval characters in anuran systematic studies, although incipient, is relatively old. Lataste (1879), Noble (1926) and Orton $(1953,1957)$ proposed the use of morphological features such as the spiracle (structure through which water is evacuated from the branchial chambers) and external mouthparts of tadpoles to complement the classification of Anura. Orton (1953) grouped the described tadpoles in four basic types and pointed out that some characters are quite variable while others are more conserved. However, some authors questioned the validity of using these characters in systematic analysis (Griffiths 1963; Griffiths and de Carvalho 1965; Sokol 1975). This controversy proceeds from the low number of characters analysed by Lataste (1879), Noble (1926) and Orton (1953), which could cause misinterpretations regarding systematic relationships among families of Anura.

Internal larval characters tend to be phylogenetically conserved (i.e. characters show low homoplasy), having a great potentia for use in phylogenetic studies (Andrade et al. 2007) that could be used together with adult characters and molecular data (Wassersug 1980). Diverse systematic studies using both internal buccal and larval cranial structures have been conducted (e.g. Wassersug and Heyer 1988; Larson and de Sá 1998; Haas 2003 Pugener et al. 2003), expanding our knowledge of the morphological diversity of tadpoles and anuran systematics. Considering the family Leptodactylidae Werner, 1896, larger systematic studies with thses types of characters are absent, with the exception of some studies that have described the internal buccal morphology (e.g. Wassersug and Heyer 1988; Vera Candioti et al. 2007) and larval cranium (Larson and de Sá 1998; Vera Candioti et al. 2007). Wassersug and Heyer (1988) analysed buccal microanatomy of eight species of Leptodactylus Fitzinger, 1826. Larson

Corresponding author: Núbia Esther de Oliveira Miranda (estherbio@ gmail.com)

Contributing authors: Natan Medeiros Maciel (nmaciel@gmail.com), Karla Pêssoa Tepedino (karlaptp@gmail.com), Antonio Sebben (sebben@unb.br) and de Sá (1998) conducted an extensive description, comparison and a phylogenetic inference from the morphological features of larval cranium in 22 species of Leptodactylus. But studies involving the use of both sets of characters (internal buccal morphology and larval cranial) in Leptodactylus systematics have not been conducted.

Until recently, Leptodactylidae was a polyphyletic assemblage divided into five subfamilies (Ruvinsky and Maxson 1996; Frost et al. 2006). Frost et al. (2006) combined anatomical characters described by Haas (2003) and molecular data to establish a new system for Lissamphibia. Grant et al.(2006) analysed molecular and phenotypic characters (morphology of adults and larvae, skin secretion molecules and behavioural data) and implemented changes in the systematics proposed by Frost et al.(2006). Pyron and Wiens (2011) with a comprehensive sampling of taxa proposed a new molecular phylogenetic hypothesis for Amphibia. As a result of these studies, Leptodactylidae is currently composed of 200 species allocated in three subfamilies: Leiuperinae Bonaparte, 1850; Leptodactylinae Werner, 1896; and Paratelmatobiinae Ohler and Dubois, 2012 (Pyron and Wiens 2011; Frost 2014).

In the Leptodactylinae, Leptodactylus is the most diverse genus, containing 76 species distributed from North America (southern Texas) through Central and South America. Heyer (1969) described five phenetic groups in the genus based on behavioural attributes, morphology and ecology of adults. Although several systematic studies of these groups were performed by Heyer $(1970,1973,1974,1978,1979,2005)$, the phylogenetic relationships of members of Leptodactylus and the family Leptodactylidae are not fully resolved (e.g. Larson and de Sá 1998; Frost et al. 2006; Ponssa 2008).

In an early phylogenetic study of Leptodactylus, Heyer (1998) used characters of adult morphology and larval buccal morphology, morphological features of eggs and vocalization parameters to demonstrate that Leptodactylus is paraphyletic in relation to Adenomera Steindachner, 1867, Lithodytes Fitzinger, 1843, and Vanzolinius Heyer 1974. Frost et al. (2006) suggested that the genus Leptodactylus was monophyletic only if Adenomera and Lithodytes are included, and the genus Vanzolinius was 
a synonym of Leptodactylus. Nevertheless, most authors recently rejected these conclusions (e.g. Ponssa 2008) because only few species had been sampled. Pyron and Wiens (2011) and Fouquet et al. (2013) considered Adenomera as a monophyletic valid genus. The phylogenetic hypothesis of Larson and de Sá (1998), based on characters of the larval cranium, neither supported the monophyly of the genus Leptodactylus nor the relationships among the groups proposed by Heyer (1969). Ponssa (2008) published a phylogenetic hypothesis for the L. fuscus group, based on external morphology, osteology, larval cranial morphology and behaviour. She corroborated the monophyly of the L. fuscus group and hypothesized that the L. pentadactylus and L. fuscus groups were sister groups.

We report on a comparative analysis of the larval internal buccal morphology and larval cranial of species of Leptodactylus to: (1) describe and investigate the use of new larval characters in phylogenetic studies of Leptodactylus, (2) propose a phylogenetic hypothesis for the genus, (3) assess the impact of larval characters on a combined tree, generated by larval (present work) and adult (previous analysis) characters and (4) evaluate congruence between these different datasets.

\section{Material and Methods}

\section{Sampling}

Tadpoles and eggs of Leptodactylus species were collected in the field, and additional biological materials were obtained from scientific collections. Nineteen species of 30 different populations were sampled (Table S1). Three tadpoles, preferably at Stage 36 (Gosner 1960), of each species were dissected to examine internal buccal morphology, and three were also cleared and stained to examine the larval cranium.

\section{Internal buccal morphology}

The floor and roof of the oral cavity were exposed following the dissection procedure described by Wassersug (1976). Mouthparts were stained with methylene blue 5\% and Sudan Black B + methylene blue, submerged in water and photographed with a stereomicroscope equipped with a digital photographic system. The identification and description of buccal structures are based on the terminology proposed by Wassersug (1976)

\section{Larval cranial morphology}

Tadpoles were cleared and stained following the protocols of Dingerkus and Uhler (1977) and Song and Parenti (1995), with modifications. Observations, measurements and photographs of larval cranium structures were conducted with a stereomicroscope with eyepiece micrometre and digital photographic system. The identification and description of the structures are based on terminology employed by Larson and de Sá (1998), Cannatella (1999) and Haas (2003).

\section{Phylogenetic analyses}

Characters coded based on previous studies - 12 characters of Larson and de Sá (1998) and nine characters of Prado (2006) - were used as described by the authors or adapted as needed (Tables S2 and S3). Character states of the internal buccal and larval cranium morphology for Leptodactylus gracilis (Duméril and Bibron, 1840), L. notoaktites Heye 1978 and L. pustulatus (Peters, 1970) are based on published descriptions (Wassersug and Heyer 1988; Larson and de Sá 1998; de Sá et al. 2007a, b) and accounts of the buccal microanatomy of L. labyrinthicus (Spix, 1824), L. petersii (Steindachner, 1864), L. podicipinus (Cope, 1862) and L. vastus Lutz, 1930 by Vieira et al. (2007) and Miranda and Ferreira (2008, 2009)

Among the 76 species of the genus Leptodactylus, 19 were sampled in this study (Table S1). Five species of four genera that have been suggested to be close relatives of Leptodactylus (Larson and de Sá 1998;
Frost et al. 2006; Grant et al. 2006; Ponssa 2008) were used as outgroups: Alsodes vanzolinii (Donoso-Barros, 1974); A. verrucosus (Philippi, 1902) (Alsodidae); Ceratophrys cranwelli Barrio, 1980 (Ceratophryidae); Telmatobius scrocchii Laurent and Lavilla, 1986 (Telmatobiidae); and Crossodactylus gaudichaudii Duméril and Bibron, 1841 (Hylodidae). Character states of outgroups were obtained from the literature (Lavilla and Fabrezi 1992; Larson and de Sá 1998; Ramón Formas and Brieva 2004; Vera Candioti 2005; Weber and Caramschi 2006; Vera Candioti 2008). Characters varying between populations were treated as polymorphisms and were included in the analysis. Maximum parsimony analyses using heuristic searches were implemented in PAUP $4.0 \mathrm{~b} 1$ (Swofford 1998) and TNT 1.1 (Goloboff et al. 2003). Treelength, indices (consistency and retention) and character changes in the clades of cladograms were analysed with MACCLADE 4.0 (Maddison and Maddison 1992) and Mesquite 2.71 (Maddison and Maddison 2009). In heuristic searches, the most parsimonious trees were found by 2000 multiple random addition sequences, and the method of branch swapping was tree bisection and reconnection (TBR), retaining replicate trees. Support for clades was obtained by bootstrap analysis of 10000 pseudoreplications (Felsenstein 1985; Hillis and Bull 1993; Müller 2005) and by Bremer support (Bremer 1994). Bootstrap values were calculated by PAUP 4.0b1 and Bremer support by TNT 1.1. All series of transformations were considered as unordered and unweighted.

\section{Impact of larval characters to infer Leptodactylus phylogeny and homogeneity test}

We also assessed the impact of larval characters to infer the relationships of species of the Leptodactylus genus. To evaluate this impact, we conducted the following steps: (1) we combined the larval partition generated in the present work with the data set of Ponssa 2008) (see Fig. 1 representing the schematic diagram of partitions used in the combined analysis). Note that we excluded Ponssa's larval characters because these originated from Larson and de Sá's (1998) work and were replaced by our own data. In our data matrix, characters 1-98 are derived from Ponssa (2008) and characters 99-182 were from this work (Data S1). Only species sampled in both studies were included in the combined analysis resulting in 18 terminal taxa, and (2) a phylogenetic analysis was performed (under maximum parsimony) with these two partitions combined. The most parsimonious trees were obtained by 2000 multiple random addition sequences using the method of branch swapping (TBR) (TNT 1.1), and (3) by performing a Partitioned Bremer Support (PBS) analysis (Gatesy et al. 1999). PBS examines the impact of each partition (among multiple partitions) to the overall tree, estimating support values to each node produced by each data set. PBS analysis was conducted in TNT 1.1 by using the script published by Peña et al. (2006).

A test of homogeneity (incongruence length difference ILD) (Farris et al. 1995; Dolphin et al. 2000) to verify congruence between the two partitions was implemented in PAUP, with 1000 replications, random additions of taxa and heuristic search.

\section{Results}

\section{Overview of Leptodactylus internal larval morphology}

Overall, the buccal morphology among Leptodactylus tadpoles presented two remarkable features: the diversity of structures and reduction (in size and quantity) of these structures (Fig. 2). The infralabial papillae are small and simple in most species studied, except in $L$. riveroi where those are more complex. The number of papillae delimiting of the buccal floor arena showed a large variation. Some tadpoles as $L$. chaquensis and L. latrans have more papillae (Fig. 2A). Also, the presence of a glandular zone is clearly noticed in the species of aquatic habits such as $L$. natalensis, L. latrans, L. petersii, L. podicipinus and L. pustulatus (Fig. 2B-D). These species are known to deposit the spawn directly in water bodies and tadpoles developed entirely in the aquatic environment (Heyer 1969). Conversely in tadpoles of L. riveroi, L. rhodomystax, L. vastus, L. knudseni and L. labyrinthicus (Fig. 2E-F), buccal structures are particularly reduced. 
(a) 113 characters

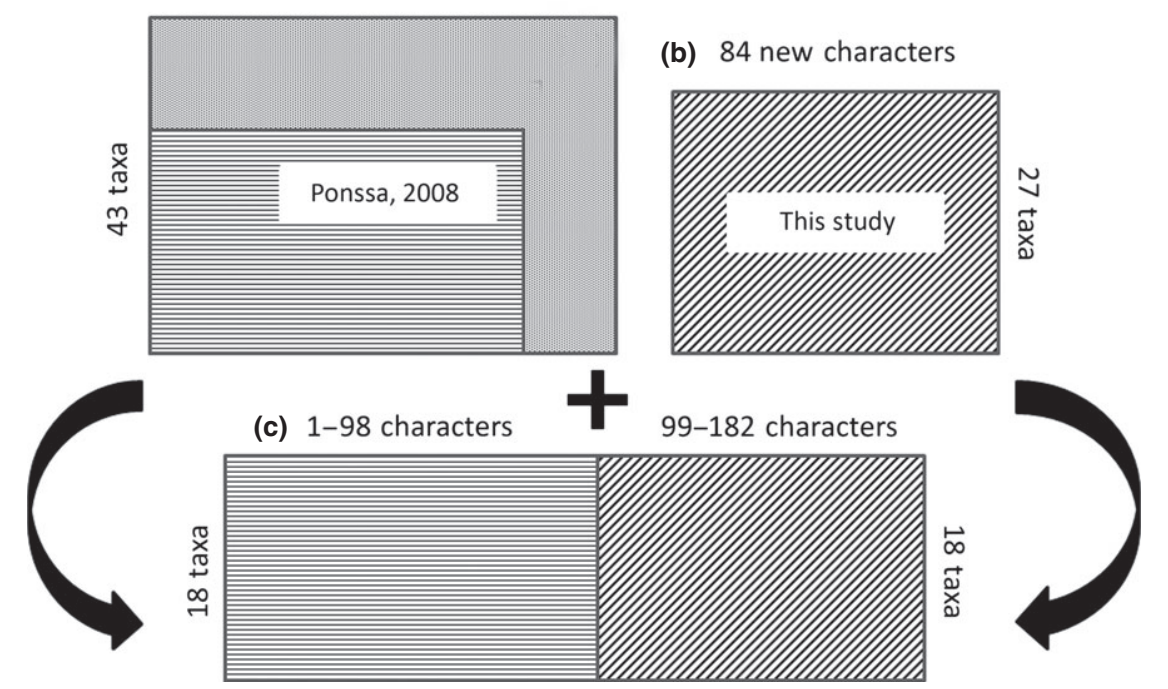

Figure 1. Schematic diagram representing how different matrices were combined to this study. One data set was taken from Ponssa (2008), originally containing 43 taxa and 113 characters (complete square at top left). We deleted Ponssa's larval matrix characters [99-113] (cross-hatched; a), eliminating 25 species and 15 characters. The second was obtained from this work, eliminating 16 species (diagonal stripes; b). The resulting matrix is then shown in c: characters 1-98 are derived from Ponssa (2008) (horizontal stripes) and characters 99-182 from this work (diagonal stripes; 84 characters). Only species sampled in both studies were included in the analysis. The total data set examined in this study therefore represented 18 taxa and 182 characters.

The reduction in the number of papillae in the buccal roof arena is a widespread feature in Leptodactylus, reaching the full absence in L. riveroi (Fig. 2G).

Among larval cranium, we found nine features common to all Leptodactylus species sampled: processus posterior dorsalis in alas of suprarostral; crista parotica; commisura quadratoorbitalis; processus dorsomedialis, $p$. ventromedialis and p. retroarticularis present in Meckel's cartilage; ceratobranchials fused to the hypobranchial plates; lateral projections present in ceratobranchials I, II and III; p. branchialis anterior; palatoquadrate narrow anteriorly and broad and slightly rounded posteriorly and otic capsules representing about $30 \%$ of the total cranial length (Fig. 3).

To illustrate the structures of floor and roof of buccal cavity, larval cranium was analysed in the present work (see Figs 2 and $3)$. These figures help to understand how characters were delimited and coded. Full morphological descriptions of buccal anatomy and larval cranium of Leptodactylus species are in preparation for further publication.

\section{Phylogeny reconstuction using larval characters}

Our anatomical analysis resulted in a matrix of 42 characters of internal oral features and 42 larval cranium characters (Data S2). Characters are listed in Table S2 (internal oral morphology) and Table S3 (larval cranium morphology), where 63 of them were described for the first time (35 from internal oral and 28 of larval cranium morphology). In the 24 taxa examined, three of the 84 characters were uninformative. Heuristic searches resulted in four most parsimonious trees (Data S3) with an optimal parsimony score of 417 steps. The strict consensus cladogram (Fig. 4) has 423 steps, a consistency index of 0.371 , a consistency index excluding uninformative characters of 0.366 and a retention index of 0.484 .

The genus Leptodactylus is recovered as monophyletic, supported by the following buccal morphological characters (Character number: State; Data S2): triangular buccal floor arena (10:1); slightly prominent projections on the posterior margin of ventral velum (17:1); postnarial arena small (27:0); lateral ridge papillae small (30:1); and glandular zone of the dorsal velum occupying half the surface (41:1). Larval cranium characters supporting the monophyly of Leptodactylus are as follows (Character number: State; Data S2): ventromedial fusion of the corpus of the suprarostral narrower than the body (43:1); presence of ventrolateral projections in the corpus of suprarostral (44:1); posterolateral extension of the palatoquadrate extends beyond the anterior margin of otic capsules (63:3); angle between the posterior margin of the processus ascendens and the braincase between $70^{\circ}$ and $80^{\circ}$ (65:1); presence of the commisura quandratoorbitalis (70:1); Meckel's cartilage long and curved (71:1); pars reuniens and Copula II with the same length (74:0); processus urobranchialis wide (77:1); lateral process of the ceratobranchial triangular (78:1); and presence of projections just in the posterior portion of ceratobranchials $(84: 2)$.

Our phylogenetic analysis of larval characters produced two major clades within Leptodactylus (Fig. 4). One (clade 1) is composed of species traditionally assigned to the L. fuscus group (L. bufonius Boulenger, 1894; L. camaquara Sazima and Bokermann, 1978; L. latinasus Jiménez de la Espada, 1875; L. troglodytes Lutz, 1926; L. notoaktites; L. mystacinus (Burmeister, 1861); L. tapiti Sazima and Bokermann, 1978; L. furnarius Sazima and Bokermann, 1978; L. gracilis; L. spixi Heyer, 1983; and L. fuscus), the L. latrans group (L. chaquensis Cei, 1950 and L. latrans) and the L. melanonotus group [L. natalensis Lutz, 1930; L. petersii, L. podicipinus and L. pustulatus (Peters, 1870)]. Leptodactylus bufonius and L. camaquara are successive basal branches in this clade, which is supported by the following characters of internal oral anatomy: infralabial posterolateral papillae conical or triangular (5:1); triangular median ridge (28:3); and absence of pustules and/or papillae on the posterior and/or bottom of the dorsal velum (42:0). Four larval cranium characters also support the clade 1: otic capsules representing $30 \%$ or more of the length of larval cranium (54:1); cornua trabeculae representing over $20 \%$ of the length of larval cranium (60:0); posterolateral extension of the palatoquadrate reaching the level of attachment of processus ascendens to the braincase (63:1); and hypobranchial plates separated (80:0). 

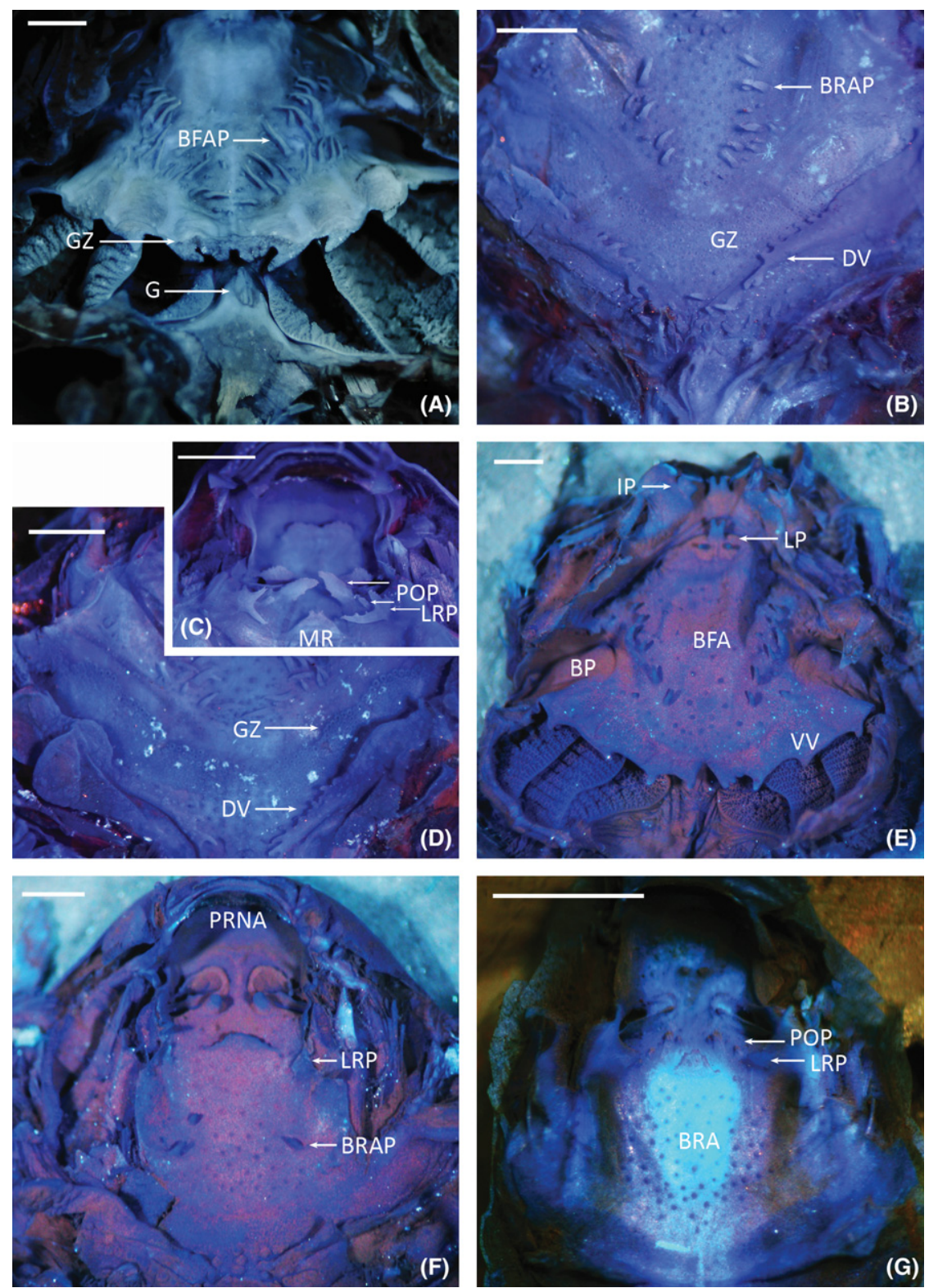

Figure 2. Overview of internal buccal morphology: (A) buccal floor arena papillae and glandular zone in buccal floor of Leptodactylus latrans, stage 36 (Gosner 1960); (B) glandular zone in buccal roof of L. chaquensis, stage 37; (C and D) prenarial and postnarial arena, postnarial papillae, lateral ridge papillae, median ridge and glandular zone of the buccal roof of L. latrans, stage 36; (E and F) reduction of the structures in buccal floor and roof of L. knudseni, stage 34; (G) absence of the buccal roof arena papillae in L. riveroi, stage 26. BFA, buccal floor arena; BP, buccal pocket; BFAP, buccal floor arena papillae; BRA, buccal roof arena; BRAP, buccal roof arena papillae; DV, dorsal velum; G, glottis; GZ, glandular zone; IP, infralabial papillae; LP, lingual papillae; LRP, lateral ridge papillae; MR, median ridge; POP, postnarial papillae; PRNA, prenarial arena; VV, ventral velum. Scale bars $=1.0 \mathrm{~mm}$.

The other clade (clade 2; Fig. 4) comprises the species Leptodactylus labyrinthicus, L. knudseni Heyer, 1972 and L. vastus, which traditionally have been assigned to the $L$. pentadactylus group. This clade is defined by five character states of internal buccal anatomy: central papillae anteriorly positioned in relation to lateral papillae (9:1); buccal floor arena rectangular or trapezoidal (10:3); more than 30 pustules on the buccal floor arena (11:2); five or less papillae limiting the buccal roof arena (13:1); and posterior wall of the nostrils low (24:0). Among the larval cranium characters are suprarostral corpus and alas of the same width (47:0); a distinct processus posterolateralis at the crista parotica (62:0); and Meckel's cartilage short and curved (71:0).

Bootstrap and Bremer supports indicate that Leptodactylus is a monophyletic clade well supported in the analyses with $82 \%$ and

J Zoolog Syst Evol Res (2015) 53(1), 55-66

(C) 2014 Blackwell Verlag GmbH decay index of 5, respectively. The clade (L. vastus + (L. knudseni + L. labyrinthicus)) has a bootstrap support of $79 \%$ and Bremer support of 5 . The clade composed of species of groups $L$. fuscus, $L$. melanonotus and $L$. latrans has a Bremer value of 3. The clade ((L. chaquensis + L. latrans $)+($ L. pustulatus $+(L$. podicipinus $+(L$. natalensis $+L$. petersii $))))$ has a bootstrap support of $60 \%$ and a Bremer of 5 .

\section{Impact of larval characters to infer Leptodactylus phylogeny} and homogeneity test

The analysis of 182 characters and 18 taxa (Data S1) reveals 18 constant characters, and 34 uninformative and 130 informative characters. We recovered 25 most parsimonious trees (Data S4) 

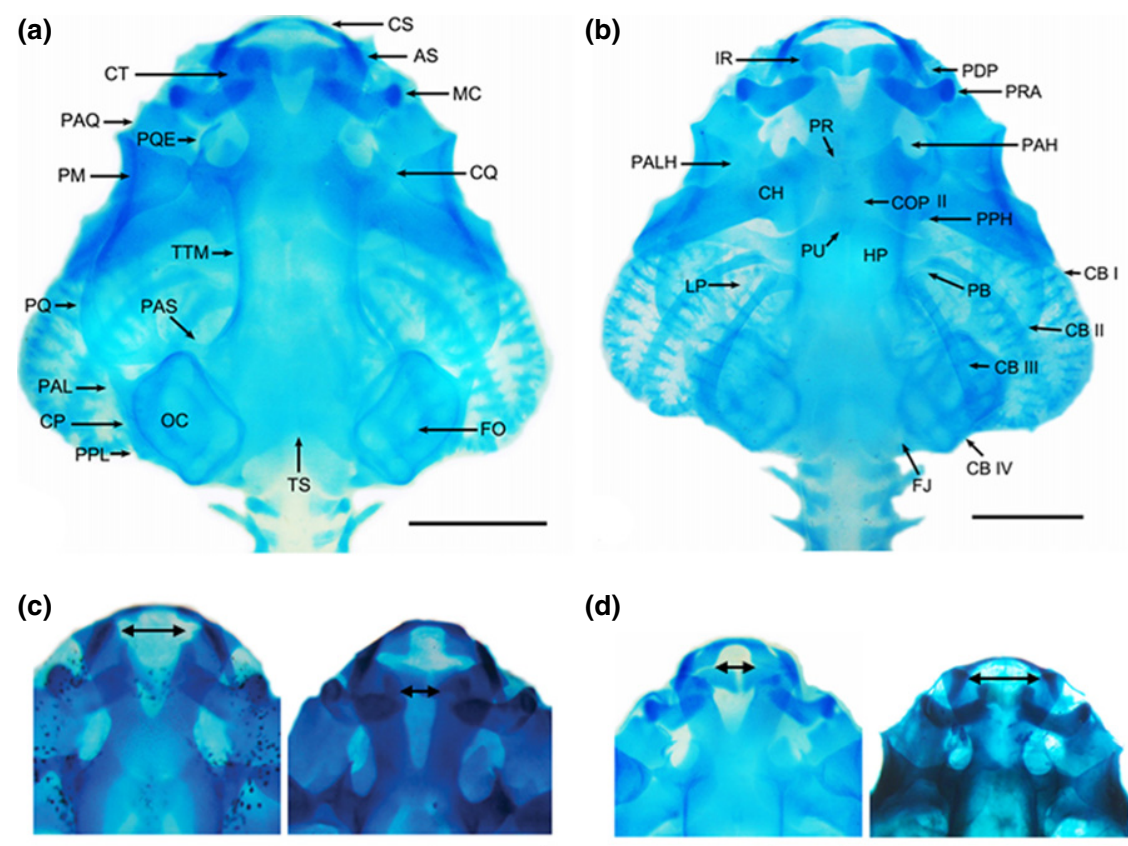

(d)

(e)

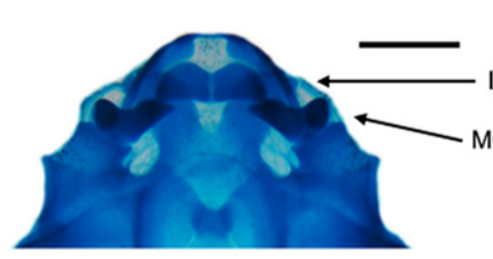

(g)
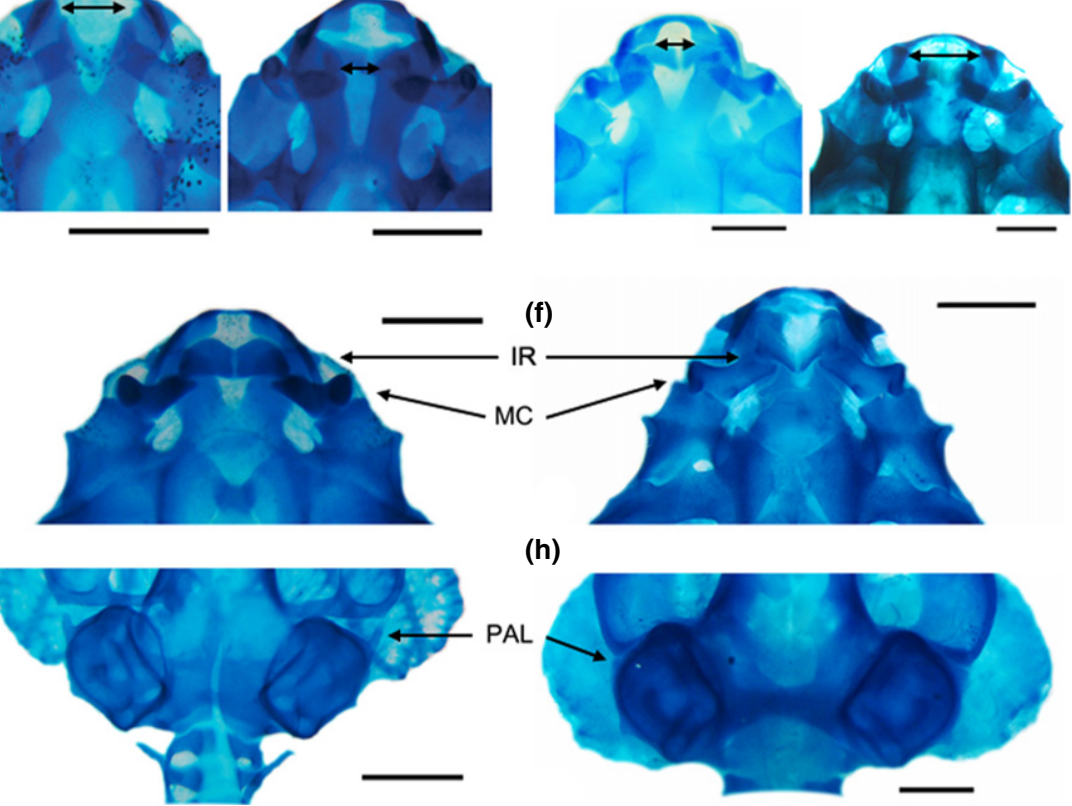

(f)

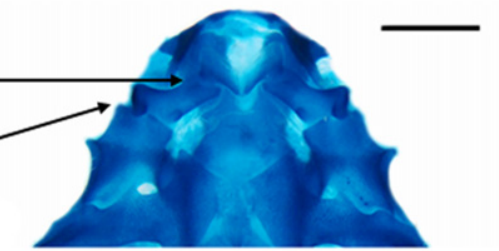

(h)

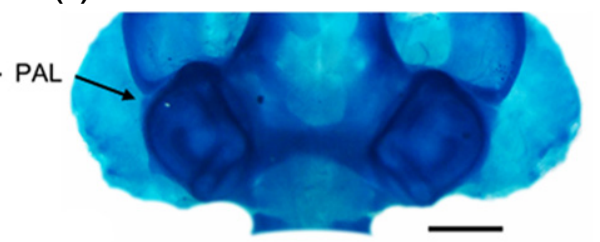

Figure 3. Representations of larval cranium morphologies of Leptodactylus tadpoles: (a-b) dorsal and ventral overviews of L. fuscus, stage 38 (Gosner 1960); (c) the arrows represent the two states of the Character 56 (angle between cornua trabeculae in relation to the width of larval cranium) of L. camaquara, stage 29 (state 1, left figure) and L. furnarius, stage 32 (state 0, right figure); (d) the arrows represent the two states of the Character 49 (space between the corpus of suprarostral) of $L$. troglodytes, stage 35 (state 0 , left figure) and L. chaquensis, stage 35 (state 1, right figure); (e-f) robustness of infrarostral elements and states of Meckel's cartilage, L. knudseni, stage 33 (more robust, state 0) and L. tapiti, stage 39 (less robust, state 1); (g-h) represent two states of the Character 61 (processus anterolateralis of crista parotica), L. furnarius, stage 32 (state 3) and L. vastus, stage 34 (state 1). AS, alas of suprarostral; $\mathrm{CB}$, ceratobranchials; $\mathrm{CH}$, ceratohyal; $\mathrm{COP}$, copula; $\mathrm{CP}$, crista parotica; $\mathrm{CQ}$, commisura quadratoorbitalis; CS, corpus of suprarostral; CT, cornua trabeculae; FJ, foramen jugulare; FO, fenestra ovalis; IR, infrarostral; HP, hypobranchial plates; LP, lateral projections; MC, Meckel's cartilage; OC, otic capsule; PAH, p. anterior hyalis; PALH, p. anterolateralis hyalis; PAL, processus anterolateralis; PAQ, pars articularis quadrati; PAS, $p$. ascendens; $\mathrm{PB}, p$. branchialis; $\mathrm{PDP}, p$. dorsalis posterior; $\mathrm{PM}, p$. muscularis quadrati; PPL, $p$. posterolateralis; $\mathrm{PPH}, p$. posterior hyalis; $\mathrm{PQ}$, palatoquadrate; $\mathrm{PQE}$, p. quadratoethmoidalis; PR, pars reuniens; PRA, p. retroarticularis; PU, p. urobranchialis; TS, tectum synoticum; TTM, taenia tecti marginalis. Scale bars $=1.0 \mathrm{~mm}$.

with 487 steps each. The strict consensus cladogram (Fig. 5a) has 557 steps, a consistency index of 0.472 , a consistency index excluding uninformative characters of 0.424 and a retention index of 0.309 .

The monophyly of the genus Leptodactylus is supported, but there are some polytomies (Fig. 5a). However, close relationships among the species allocated to the L. fuscus, L. latrans, $L$. melanonotus and the $L$. pentadactylus groups are maintained. Thirty-five characters with unambiguous changes support the Leptodactylus clade; among these, 12 characters were provided by Ponssa (2008).

It is expected that if the PBS results' partitions (in this case, larval and adult characters; see Fig. 1) support a relationship rep- resented by a node in the combined tree, then the PBS value will be positive. If, conversely, a partition supports an alternative relationship, the PBS value will be negative. The magnitude of PBS values indicates the level of support for or disagreement with a node. Our results of PBS test revealed that each data set (larval and adult characters) was congruent and supports monophyly of the Leptodactylus clade (Fig. 5a; both positive values). Although, this contribution shows to differentially support this arrangement (2.8 for adult characters and 6.2 for larval characters). The clade formed by Leptodactlyus chaquensis $+L$. podicipinus and the other by L. knudseni + L. labyrinthicus (Fig. 5a) contributed differentially for this arrangement (both -5.2 for adult characters and 8.2 for larval characters). Adult and larval 


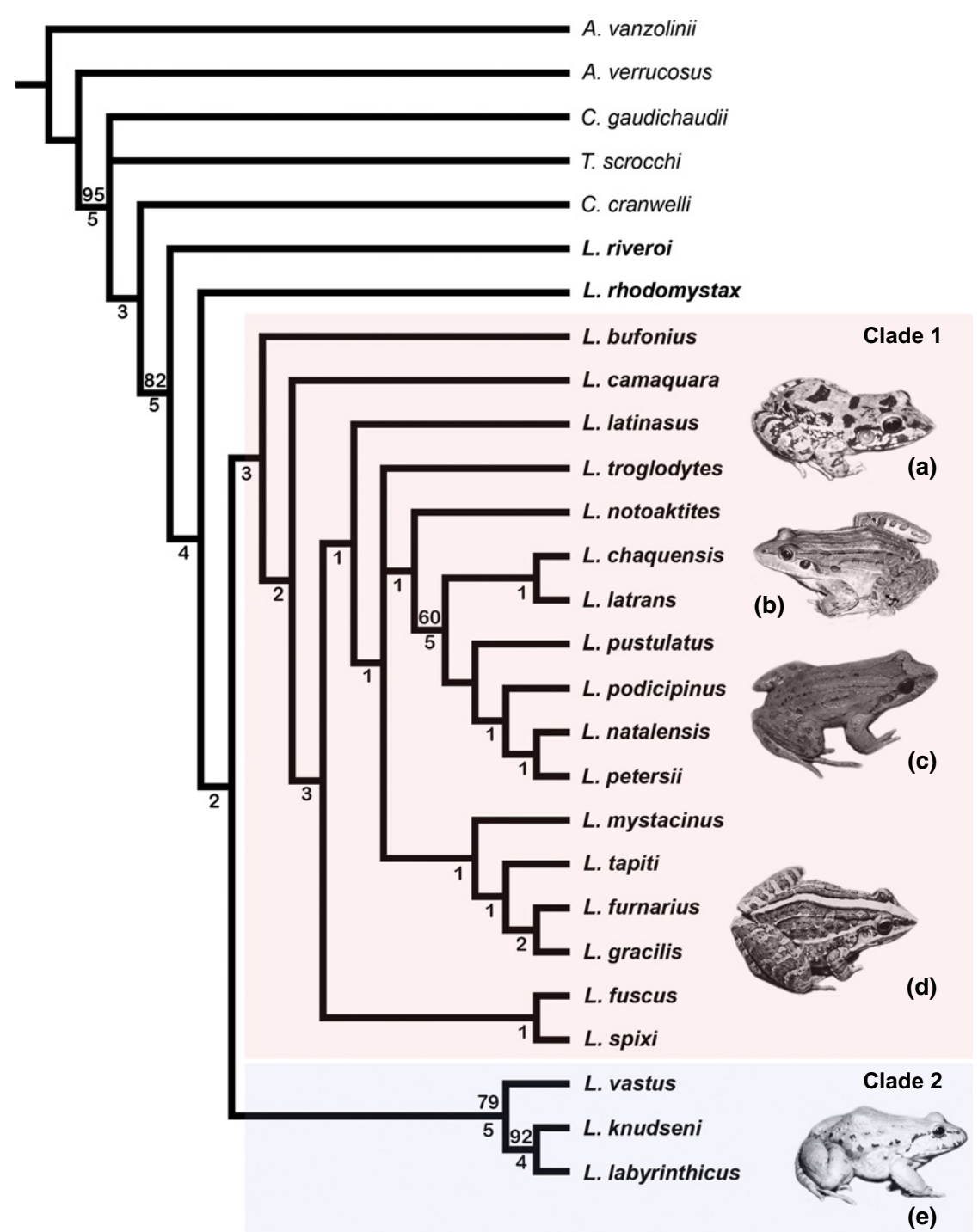

Figure 4. Strict consensus cladogram from the maximum parsimony analysis of 84 larval characters (length $=423$ steps, $\mathrm{CI}=0.366$ and $\mathrm{RI}=0.424$; excluding uninformative characters). Numbers above nodes are bootstrap values and below the Bremer support values. (a) Leptodactylus troglodytes (L. fuscus group); (b) L. latrans (L. latrans group); (c) L. podicipinus (L. melanonotus group); (d) L. fuscus (L. fuscus group); and (e) L. labyrinthicus (L. pentadactylus). Photos a, b and e by Antonio Sebben. Photos c and d by Ariovaldo A. Giaretta.

characters support the clade formed by L. knudseni + L. labyrinthicus + L. rhodomystax; however, both contributed with small values to this representation ( 0.8 for adult characters and 0.2 for larval characters; Fig. 5a).

The homogeneity test showed that the compared partitions (present work and Ponssa's) are incongruous ( $p<0.001$ ).

The $50 \%$ majority rule consensus tree of the combined analyses (Fig. 5b) is more similar to the tree based only on larval characters. We recovered a large clade composed by species of the $L$. fuscus, L. latrans and L. melanonotus groups, and another composed by species of the L. pentadactylus group. The bootstrap analyses of the strict consensus tree support the Leptodactylus clade to a level of $96 \%$.

\section{Discussion}

Polymorphisms found in internal larval morphologies of Leptodactylus

We recorded intraspecific and populational morphology variation among tadpoles sampled. Intraspecific and intrapopulational vari- ations in buccal morphology were equally observed between the left and right sides of the same individual. The features with variations were the amount of pustules throughout arenas of floor and buccal roof and the amount of papillae rounding it, as well as the presence of pustules or papillae in the region anterior to buccal pocket. These kinds of variation (quantity) are expected and therefore should not be used to systematic of tadpoles (Wassersug and Heyer 1988). But the disproportion among variations (extensions) observed could be used for phylogenetic reconstruction purpose.

Interpopulational variations in buccal morphology could be evaluated only in cases of species sampled for more than one locality: L. chaquensis, L. fuscus, L. mystacinus, L. latrans, L. podicipinus and L. troglodytes. Leptodactylus chaquensis and L. latrans presented variation in infralabial papillae. In the first species mentioned, we found four infralabial papillae in Argentinian populations and three in the population from Corumbá municipality, Mato Grosso do Sul state, Brazil. Populations of L. latrans from Brazilian states of Paraná, São Paulo and Roraima presented three infralabial papillae, while population of 

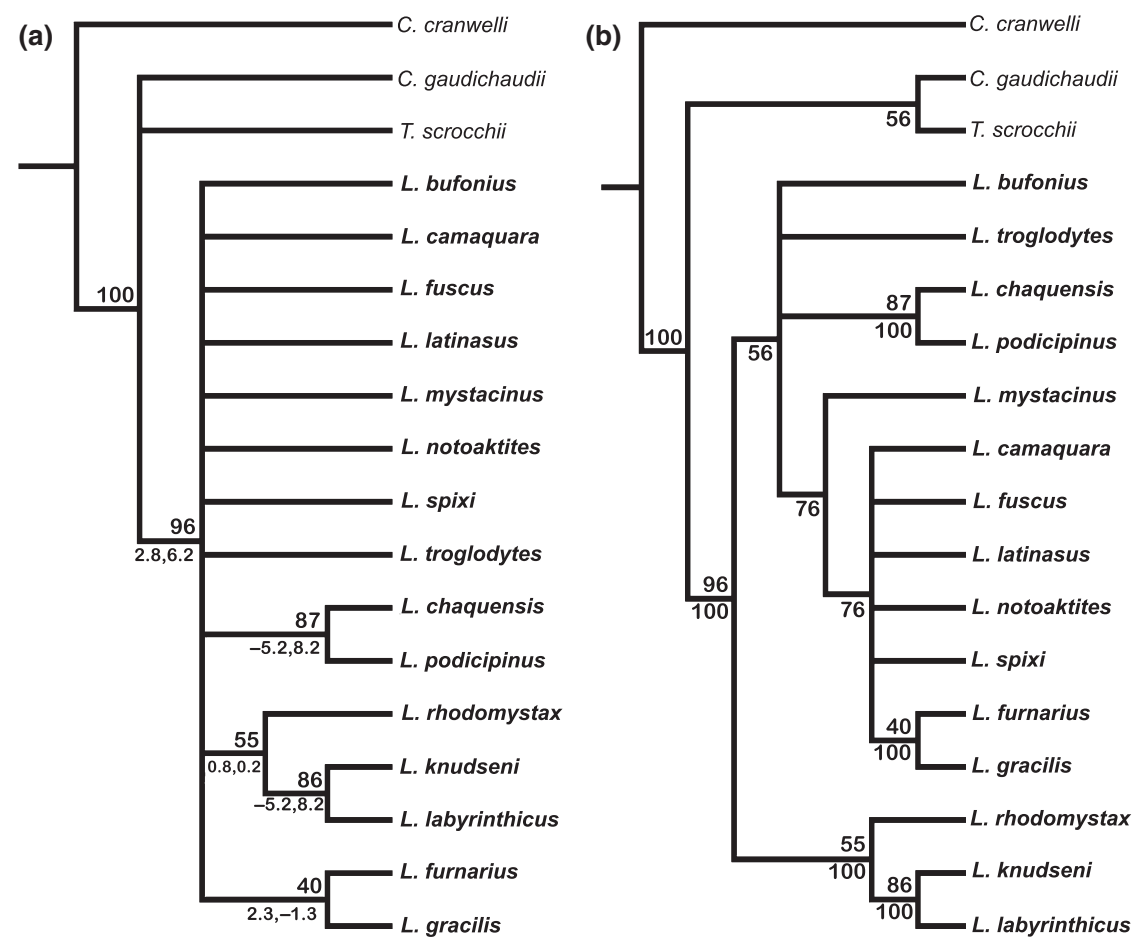

Figure 5. Combined maximum parsimony analysis of 98 characters of external morphology, osteology, ethology and morphometric data of adult specimens (Ponssa 2008) and 84 larval characters. (a) strict consensus cladogram (length $=557$ steps, $\mathrm{CI}=0.472$ and RI $=0.309$ ). Numbers above nodes are bootstrap values, and PBS values are found below nodes inside squares (adult characters left, larval characters right). (b) $50 \%$ majority rule consensus cladogram (length $=11$ steps, $\mathrm{CI}=0.580, \mathrm{RI}=0.550$ ). Numbers above nodes are bootstrap values and below the frequencies of clades.

Seropédica municipality, Rio de Janeiro state, presented five. Populations of L. latrans also presented variations in lingual papillae. The populations from Brazilian states of Paraná, São Paulo and Roraima presented four lingual papillae, and population of Rio de Janeiro state presented three lingual papillae. The amount of dispersed pustules on the arena of buccal floor was a quite variable character, being all the species already mentioned presenting such variation. The number of papillae limiting the arena buccal floor varied in populations of Leptodactylus fuscus. Population from Chapada dos Guimarães National Park in Mato Grosso Brazilian state showed a greater amount of papillae limiting the arena (Miranda and Ferreira 2009). Differences in height of the nostrils posterior wall were observed in tadpoles of L. mystacinus and L. podicipinus (Miranda and Ferreira 2009). Tadpoles of L. mystacinus from Argentina presented four postnarial papillae per side and the individuals collected in Brasília, Federal District, Brazil, two papillae per side. The median ridge was relatively small in species examined as already demonstrated by Wassersug and Heyer (1988), although the shape gradually varied between semicircular to triangular in L. fuscus, L. latrans and L. troglodytes. The shape of lateral ridge papillae varied in tadpole populations of $L$. latrans. Individuals from Paraná, São Paulo and Rio de Janeiro Brazilian states presented ramificated and complex papillae, while tadpoles from Roraima Brazilian state presented chela-shaped lateral ridge pappilae. The shape of the buccal roof arena presented by L. fuscus and L. podicipinus varied between triangular and trapezoidal. Differences in amount of pustules in the buccal roof arena were observed in tadpoles of L. podicipinus as already verified by Miranda and Ferreira (2009).

Differences in the buccal morphology and larval cranium presented less intraspecific and populational variations. Features presented intraspecific variation were ceratobranchial process, ornamentations of etmoidal plate and fusion of infrarostral ele- ments. Interpopulational variations also were observed. The population of Leptodactylus fuscus from Monte Alegre municipality, Goiás state, Brazil, showed a processus dorsalis posterior of alas widest than the remaining populations examined. Adostrals were observed in L. mystacinus tadpoles from Brasília, Federal District, Brazil, and $L$. troglodytes of Monte Alegre municipality. However, we could not observe this feature in Argentinian tadpole populations of $L$. mystacinus and L. troglodytes from João Pessoa municipality, Paraíba state, Brazil. Differences in length and width ratio of larval cranial were found in L. chaquensis, L. mystacinus and L. latrans. The frontoparietal fontanelle is subdivided in tadpoles of L. latrans from Paraná, São Paulo and Roraima states of Brazil, but not partitioned in individuals from Seropédica municipality, Rio de Janeiro state, Brazil. Variation in size of $p$. urobranchialis was observed in populations of $L$. chaquensis, $L$. fuscus and $L$. latrans and the fusion degree if hypobranchial plates in L. fuscus, L. mystacinus and $L$. latrans.

These findings point the demand for further interpopulational studies in tadpoles. Langone and de Sá (2005) showed variations regarding external morphology of $L$. fuscus. Besides, works dealing with internal morphological variations in tadpoles are lacking. The species for which these variations were observed to present a wide distribution could be possibly a different species. These variations could indicate the need to conduct taxonomic revisions in these species, analysing the characters of the tadpoles as well as adults and molecular data (Wynn and Heyer 2001).

\section{Performance of internal buccal larval morphology characters}

This is an innovative work that accessed internal buccal characters to test its contribution to the study of phylogenetic inference in the genus Leptodactylus. Wassersug and Heyer (1988) suggested that buccal larval characters should not be used in phylogenetic studies. They argued that internal buccal morphology is 
strongly correlated with the larval ecology, and homoplasticity may render buccal characters phylogenetically uninformative. Nonetheless, these authors also argued that there was a phylogenetic pattern in buccal characteristics. This set of data was not exploited in previously published phylogenetic analyses that used larval characters (Larson and de Sá 1998; Maglia et al. 2001; Haas 2003; Pugener et al. 2003).

We have identified four features of buccal larval anatomy that are synapomorphies of Leptodactylus, as follows:

(1) Buccal floor arena triangular (Character 10: State 1). This character state also occurs in Physalaemus Fitzinger, 1826 (Wassersug and Heyer 1988; Miranda and Ferreira 2009), suggesting that this characteristic may have arisen earlier or more than once in the evolution of anurans.

(2) Slightly prominent projections on the posterior margin of ventral velum (17:1). The presence and morphology of these projections may vary among diverse genera, but is present in all $L e$ ptodactylus sampled in this study. The codification of this character needs to be refined in future studies.

(3) Small postnarial arena (27:0). This character state is also found in other genera - for example Eupemphix Steindachner, 1863 and Physalaemus (Wassersug and Heyer 1988; Miranda and Ferreira 2009).

(4) Small lateral ridge papillae (30:1). Absence of the lateral ridge papillae is an attribute found in basal families of Anura (Pipidae, Rhinophrynidae, Alytidae, Leiopelmatidae and Bombinatoridae) (Wassersug 1980). The absence of these structures was also reported in Ceratophrys cranwelli (Ceratophryidae; Vera Candioti 2005). These observations suggest that this character may have arisen more than once in the evolutionary history of Anura, and their presence or absence may be a result of multiple evolutionary events (Maglia et al. 2001). The presence of a pair of lateral ridge papillae was observed in all previously examined Leptodactylus tadpoles.

None of the larval characters analysed are synapomorphic for the phenetic species groups of Leptodactylus. Among the 42 buccal characters, 16 are homoplastic.

(1) Presence of spherical protuberances on the anterior portion of the infrarostral region (Character 1: State 1). This character occurs in Leptodactylus chaquensis, L. latrans, L. podicipinus and L. labyrinthicus. We expected such anatomical similarity among L. chaquensis, L. latrans and L. podicipinus; though, L. labyrinthicus is not closely related. The convergence is surprising because these species do not occupy the same type of environment, having disparate dietary habits (Agostinho et al. 2002; Prado et al. 2005; Silva et al. 2005).

(2) A pair of narrowly separated medial infralabial papillae (3:2). This feature is present in Leptodactylus natalensis, L. notoaktites, L. spixi and L. vastus and shows no apparent distributional pattern.

(3) Lateral pair of infralabial papillae quadrangular $(5: 2)$. This character occurs in species that are not closely related.

(4) Lingual papillae in number of three (7:2). Lingual papillae occur in the Leptodactylus fuscus, L. latrans and L. melanonotus groups, and the L. pentadactylus clade. Associations between the larval ecology and the amount of lingual papillae are unknown.

(5) Arrangement of lingual papillae (9:1). Central papillae anteriorly positioned in relation to lateral papillae were observed in tadpoles of the Leptodactylus pentadactylus group and in L. spixi, which traditionally is placed in the L. fuscus group.

(6) More than 30 pustules on the buccal floor arena (11:2). This feature is found in many species of Leptodactylus, including those not closely related; it also occurs in the Crossodactylus gaudichaudii.
(7) Projections grouped laterally within the anterior limits of ventral velum, absent or with pustules (15:0 and 15:2). The absence and reduction in number and size of selection structures (infralabial papillae, lingual papillae and arena papillae) is related to macrophagous and carnivorous habits. Thus, the absence of these projections and their presence with reduced size (pustules) in the Leptodactylus pentadactylus group is expected. These features also occur in L. bufonius, L. camaquara, L. furnarius and L. spixi, for which there are no data on foraging habits.

(8) Prominent projections on the posterior margin of ventral velum (17:2). This character state is present in species of the Leptodactylus fuscus + L. latrans + L. melanonotus clade and also occurs in L. knudseni.

(9) More than five projections on each side of the posterior margin of ventral velum (18:1). This attribute is present in outgroups, especially in Crossodactylus Duméril and Bibron, 1841 and Telmatobius Wiegmann, 1834 (Weber and Caramschi 2006; Vera Candioti 2008), and also occurs in Leptodactylus bufonius and $L$. vastus.

(10) Orientation of choanae in relation to the longitudinal axis of the body (21:0 and 21:1). This character is highly homoplastic and variable and probably has slight systematic value.

(11) Posterior wall of the nostril, low (24:0). All tadpoles in the Leptodactylus pentadactylus clade, L. tapiti and L. spixi share this character, which has no known ecological significance.

(12) Median ridge shape (28:0 and 28:2). The median ridge is relatively small in all species of Leptodactylus previously analysed (Wassersug and Heyer 1988), but its shape is convergent in nine of 22 species examined.

(13) Border of median ridge (29:1 and 29:2). The shape of the median ridge margin also showed to be convergence in the species analysed. This character together with Character 28 indicates that this anatomical feature (median ridge) should be used with prudence in future studies.

(14) Buccal roof arena quadrangular or trapezoidal (33:3). This character state occurs in seven species of the Leptodactylus fuscus group, L. labyrinthicus and in one out-group (Telmatobius scrocchii).

(15) Dorsal velum narrow in relation to buccal roof (37:1). This feature was found in all species traditionally assigned to the Leptodactylus latrans and L. melanonotus groups, and also L. notoaktites and L. labyrinthicus. A narrow velum and the presence of a poorly developed glandular zone are associated with macrophagous larvae (Wassersug 1980), such as L. latrans and L. labyrinthicus (Agostinho et al. 2002; Prado et al. 2005; Silva et al. 2005). The dietary habits of the other species are unknown.

(16) Dorsal glandular zone occupying half the surface of the velum (41:1). This character occurs in Leptodactylus labyrinthicus; L. natalensis; L. riveroi Heyer and Pyburn 1983; and L. rhodomystax Boulenger, 1884. The reduction of this secretory structure in L. labyrinthicus and L. rhodomystax is correlated with dietary habits (Wassersug 1980; Wassersug and Heyer 1988; Hero and Galatti 1990; Agostinho et al. 2002; Prado et al. 2005; Silva et al. 2005).

Our results corroborate Wassersug and Heyer's (1988) observation that many features of larval internal buccal morphology are homoplastic. However, this does not refute the importance of including these characters in phylogenetic studies. Maglia et al. (2001) claimed that it is useful to know whether certain morphologies have evolved in parallel, because this information enables identification of potential functional or ecological pressures (in convergences), as well as the complexity of development processes. Recognition of parallelisms in developmental patterns in the evolutionary histories of taxa may yield useful insights into the homologies of the adult morphologies (Maglia et al. 2001). 
More studies should be performed to assess the utility of such characters in phylogenetic inference in anurans.

\section{Performance of larval cranium morphology characters}

Larval cranium characters have been widely used in phylogenetic studies (Larson and de Sá 1998; Maglia et al. 2001; Haas 2003; Pugener et al. 2003) and are considered to present less homoplasy than features of internal buccal morphology. We found four larval cranial characters to be synapomorphic for Leptodactylus:

(1) Ventromedial fusion of the corpus of the suprarostral narrower (Character 43: State 1). Larson and de Sá (1998) also observed this trait in Leptodactylus species.

(2) Ventrolateral projections in the corpus of suprarostral (44:1). Variably sized projections are present in all species of Leptodactylus examined. In L. fuscus $+L$. latrans + L. melanonotus (except L. bufonius) clade, the projections are small. The projections are well developed and fused in the L. pentadactylus clade and L. bufonius.

(3) Angle of the posterior margin of the processus ascendens in relation to the braincase at an angle between $70^{\circ}$ and $80^{\circ}(65: 1)$. This feature was found in most species of the genus, except members of the Leptodactylus fuscus group, in which the posterior margin of processus ascendens is nearly perpendicular to the braincase (Larson and de Sá 1998).

(4) Lateral process of ceratobranchials triangular (78:1). This feature is absent in Leptodactylus riveroi and in the L. pentadactylus clade. Few are known about its distribution, because the character has not been used before.

The clade composed by the species traditionally assigned to the Leptodactylus fuscus, L. latrans and L. melanonotus groups is supported by one synapomorphy (Character 63: State 1). The L. pentadactylus clade also is supported by one synapomorphy (47:0).

Among 42 larval cranium characters, 22 showed some degree of convergence, suggesting that this data partition has fewer homoplastic characters than does that of internal buccal anatomy, at least for Leptodactylus.

(1) Presence of ventrolateral projections in the corpus of the suprarostral (Character 44: State 2). Members of the Leptodactylus pentadactylus clade and $L$. bufonius share this feature. Larson and de Sá (1998) also observed the same structure in the $L$. fuscus group (L. albilabris and L. longirostris).

(2) Broad space between the corpora of the suprarostral (49:1). Usually, the space between the corpora of the suprarostral is narrow, but it is wide in Leptodactylus chaquensis and L. latrans. These two species are morphologically similar and closely related. This characteristic (49:1) is present also in L. riveroi, found to be basal in our hypotheses (Fig. 4).

(3) Presence of adostrals (51:1). Both presence and absence of adostrals seem not to be related to common heritage because are observed in species that are not phylogenetically closely related (i.e. in-group and out-groups).

(4) Width larval cranium more than $90 \%$ of its length (52:2). Wide chondrocranium occurs in Alsodes Bell, 1843 and Ceratophrys cranwelli, in some species of the Leptodactylus fuscus + L. latrans + L. melanonotus clade and in L. knudseni.

(5) Length of the otic capsule $30 \%$ or more of the length of larval cranial (54:1). This condition is widely distributed in Leptodactylus and is unrelated to the size of the tadpoles. It was found in small (Leptodactylus riveroi, L. bufonius, L. camaquara, L. petersii, L. pustulatus, L. notoaktites and L. gracilis) and large tadpoles (L. knudseni).
(6) Ornamentation in the ethmoid plate (Character 55). This character is polymorphic and convergent among the species analysed.

(7) Narrower angle $(<10 \%)$ between cornua trabeculae in relation to larval cranial (56:0). This character occurs in outgroups, in the Leptodactylus fuscus + L. latrans + L. melanonotus clade and also in L. labyrinthicus.

(8) Presence of a taenia tecti tranversalis and taenia tecti medialis subdividing the fontanelle into a frontal and two parietal fontanelles $(57: 1)$. This character state was observed in the outgroup (tadpoles of Alsodes verrucosus) in the Leptodactylus fuscus + L. latrans $+L$. melanonotus clade and tadpoles of L. labyrinthicus and L. rhodomystax. It seems to be related to larval ontogeny and its heritage pattern is difficult to access.

(9) Foramen prooticum visible in lateral view (more than $1 / 3$ of its opening) (58:1). This character state was observed in Leptodactylus chaquensis, L. natalensis, L. podicipinus, L. spixi, L. knudseni and in Alsodes. All other species (except L. riveroi) had a small $f$. prooticum in lateral view. This character seems to be unrelated to the size of the tadpole, but as the knowledge of this structure is limited, it is necessary to examine different species to understand their distribution patterns.

(10) Foramen opticum greater than the f. oculomotorium (59:0). This state character is present in some species of the Leptodactylus fuscus + L. latrans + L. melanonotus clade and also in the tadpole of L. labyrinthicus. It seems that this character is not related to the body size or other ecological similarity between species.

(11) Length of cornua trabeculae relative to larval cranial length $(60: 1)$. Feature observed in tadpoles of Alsodes and in both clades of the genus resurrected in this phylogenetic analyses. For studies involving a greater diversity of species, a new coding could be required to elucidate the evolutionary pattern of this character.

(12) Processus anterolateralis of crista parotica small and triangular (61:0). This character occurs in Leptodactylus podicipinus and $L$. petersii. Species with similar morphologies. The character state was also observed in $L$. rhodomystax. No morphological or ecological similarities are known between L. rhodomystax and (L. petersii $+L$. podicipinus). The convergence in this character could correspond to multiple evolutionary events.

(13) Processus posterolateralis of crista parotica distinct (62:0). As this process is slender when compared to the previously mentioned, its use must be viewed with some caution as is hard to analyse, and also there is risks of loss or damage of this structure during the process of clearing and staining.

(14) Posterolateral extension of the palatoquadrate (63:2 and 63:3). We followed the coding of Larson and de Sá (1998). Characters states 0,1 and 4 are informative and non-convergent. States 2 and 3 are homoplastic, both in the in-group and outgroups, suggesting that this character requires better delineation.

(15) Triangular projection at anterolateral margin of the cornua trabecula reduced or absent (68:1). This polymorphic character is homoplastic and, thus, not phylogenetically informative.

(16) Width of processus muscularis (in dorsal view) two-thirds that of pars articularis quadrati (69:1). Leptodactylus rhodomystax shares this character with some species of the L. fuscus + L. latrans + L. melanonotus clade and members of outgroups (Alsodes and Crossodactylus). The shape of this structure is similar in all species examined.

(17) Presence of a commisura quadratoorbitalis (70:1). This character occurs in all species of Leptodactylus examined, as well as Telmatobius. This suggests that this attribute may have arisen before and/or more than once in the evolution of Leptodactylidae. 
(18) Copula II larger than the pars reuniens (74:2). Sizes are variable in both in-group and out-group.

(19) Large processus urobranchialis (77:1). The size of p. urobranchialis proved to be slightly informative and homoplastic.

(20) Processus anterior hyalis and $p$. posterior hyalis equal in size (79:1). Leptodactylus knudseni shares this character with a few other species of the $L$. fuscus $+L$. latrans $+L$. melanonotus clade.

(21) Processus branchialis closed (82:1). According to Larson and de Sá (1998), all species of Leptodactylus belonging to the $L$. fuscus and $L$. pentadactylus groups have an open p. branchialis, whereas in species of L. latrans and L. melanonotus groups and in L. riveroi and L. silvanimbus, the p. branchialis is closed - data corroborated by our analysis. Although in the clade formed by the L. latrans, L. melanonotus and the L. fuscus groups, the character is homoplastic.

(22) Ceratobranchials presenting lateral projections only in the posterior portion (84:2). This character may be plesiomorphic for Leptodactylus, which is corroborated by presence of this character state in tadpoles of $L$. riveroi and $L$. rhodomystax. But it also may have arisen more than once during the evolutionary history of the group, as it is present in L. petersii ( L. fuscus + L. latrans $+L$. melanonotus clade) and in L. labyrinthicus and L. knudseni (L. pentadactylus clade)

\section{Additional phylogenetic remarks}

The most remarkable difference between the phylogenetic hypotheses presented here and earlier ones is the fact that the monophyly of the Leptodactylus fuscus group could not be corroborated. Larson and de Sá (1998) identified two major clades in Leptodactylus (pentadactylus - fuscus and latrans - melanonotus) based on 26 characters of larval cranium morphology and suggested that the species of the L. pentadactylus group might be paraphyletic once two species placed in the L. fuscus group (L. albilabris and L. labrosus) were more closely related to the species of the $L$. pentadactylus group than any other species. We could not verify this relationship because L. albilabris (Günther 1859) and L. labrosus Jiménez de la Espada, 1875 were not sampled in this study. Ponssa (2008) corroborated the results of Larson and de Sá (1998) by showing a close relationship between those species and the L. fuscus group. Ponssa (2008) and Pyron and Wiens (2011) recovered L. fuscus group as monophyletic and most closely related to the $L$. pentadactylus group. These relationships were not corroborated in the present study. We identified two major clades - a clade formed by the $L$. fuscus $+L$. latrans $+L$. melanonotus groups and the other formed by the L. pentadactylus group. The L. latrans and L. melanonotus groups are closely related and embedded within the L. fuscus group. This major clade is closely related to the $L$. pentadactylus clade. We did not recover $L$. rhodomystax (currently considered a member of the $L$. pentadactylus group) in the $L$. pentadactylus clade; instead, L. rhodomystax is basal in relation to the two major clades - that is the L. fuscus + L. latrans + L. melanonotus clade and L. pentadactylus clade. This relationship was also recovered by Pyron and Wiens (2011). Leptodactylus riveroi is sister of all other species in the genus, suggesting that this species does not represent an evolutionary transition between the L. latrans and L. melanonotus groups (Heyer and Pyburn 1983; Larson and de Sá 1998).

Heyer (1969) suggested a close relationship between the Leptodactylus latrans and L. melanonotus groups, with the $L$. pentadactylus group being the sister group of the former two, based on behaviour, morphology and ecology of adults. The L. fuscus group formed the sister group of the large clade composed of species of the three other species groups $-L$. latrans, L. melanonotus and $L$. pentadactylus. The L. marmoratus group (now Adenomera) is not closely related to any of the aforementioned groups previously. In recent phylogenetic hypotheses, Pyron and Wiens (2011) and Fouquet et al. (2013) resurrected Adenomera as sister group of Leptodactylus species. Because we were unable to sample species of Adenomera, we have no insights on the issue. There are a few discrepancies of data processing by the present analysis and the hypothesis presented by Ponssa (2008). Ponssa (2008) ordered some characters in her analysis and also implemented the method of character successive weighting (Goloboff 1993, 1995). This methodology has been criticized (Turner and Zandee 1995; Kluge 1997; Grant and Kluge 2003), and we prefer not to implement it in the present work.

Most amphibian systematic studies include data from adult specimens and/or molecular data. However, as mentioned by Maglia et al. (2001), the morphology of an organism, including those with a bimodal life cycle, is not restricted solely to adult; it is part of a continuous ontogenetic process that includes different forms with different attributes that can be assessed. Our phylogenetic analyses based on larval and adult morphological data sets yielded the same two clades (fuscus - latrans - melanonotus and pentadactylus) for larval characters alone and combined lar$\mathrm{val}$ and adult datasets. The unique difference was the topological position of Leptodactylus rhodomystax, which was included in the L. pentadactylus clade in the combined analysis. This confirms that different classes of characters are important in the resolution of relationships among species of Leptodactylus. Unfortunately, only 15 species of Leptodactylus were included in the combined analysis. The great amount of missing data in Ponssa's (2008) data set may be a source of inconsistencies, affecting the results. It is necessary to sample a larger number of species in the genus Leptodactylus to clarify both the relationships and the behaviour of larval and adult characters. In the present work, when different partitions were combined (i.e. Ponssa 2008 and the larval characters analysed by the present work), the resulting phylogeny proved to be mostly congruent to the one obtained by using larval characters only. Hillis and Wiens (2000) suggested that subsampling characters and/or taxa may produce phylogenetic inconsistencies.

Some of the characters used in the phylogenetic analysis, both from this work and that coded by Ponssa (2008), were polymorphic. The inclusion of polymorphic characters in phylogenetic analysis does not necessarily make the matrix more informative (Wiens 2000). Some authors code polymorphic characters as missing data or chose to exclude them from analysis (Farris 1966; Kluge and Farris 1969). Although the polymorphic characters are less informative than the characters with fixed states (Wiens 1995), their inclusion is more informative than their exclusion (Wiens 2000).

PBS results suggest an incongruence produced by larval and adult characters found in many topological areas of the strict consensus tree (Fig. 4a). ILD also supports this incongruence. The considerable disagreement between two partitions on the combined trees is probably related to the nature of characters, which are subject to different evolutionary processes.

The monophyly of the Leptodactylus is corroborated by both larval and adult morphological characters. Nevertheless, the intrageneric relationships remain to be resolved as additional species, and different data sets (e.g. molecular characters) can be sampled.

\section{Acknowledgements}

We are grateful to many people who kindly collected and donated specimens. Linda Trueb kindly read the early draft of 
the manuscript and provided many suggestions and corrections. James M. Carpenter, Adalgisa F. Cabral and three anonymous reviewers provided many suggestions improving the manuscript a lot. Carlos Peña helped in the partitioned bremer support analysis. Partial financial support was provided by the Decanato de Pesquisa e Pós-graduação (DPP) and Programa de Pós-graduação em Biologia Animal from Universidade de Brasília (BIOANI). CAPES (Brazilian Ministry of Education) provided scholarships and financial support to N.E.O.M. CAPES and CNPq by the continued financial support to NMN and AS. The Brazilian Ministério do Meio Ambiente - ICMBio/RAN provided collection permits number 17310-1, Ibama's register 3079309.

\section{References}

Agostinho CA, Foresti F, Lima SL, Jim J (2002) Reproduction and population size of Leptodactylus labyrinthicus (Amphibia, Anura, Leptodactylidae). Russ J Herpetol 9:15-20.

Andrade GV, Eterovick PC, Rossa-Feres DC, Schiesari L (2007) Estudos sobre girinos no Brasil: histórico, conhecimento atual e perspectivas. In: Nascimento LB, Oliveira ME (eds), Herpetologia no Brasil II. Sociedade Brasileira de Herpetologia, Belo Horizonte, Brasil, pp 127145.

Bremer K (1994) Branch support and tree stability. Cladistics 10:295304.

Cannatella D (1999) Architecture, cranial and axial musculoskeleton. In: McDiarmid RW, Altig R (eds), Tadpoles: The Biology of Anuran Larvae. The University of Chicago Press, Chicago, IL and London, pp 52-91.

Dingerkus G, Uhler LD (1977) Enzyme clearing of alcian blue stained whole small vertebrates for demonstration of cartilage. Stain Technol 52:229-232.

Dolphin K, Belshaw R, Orme DL, Quicke DLJ (2000) Noise and incongruence: interpreting results of the incongruence length difference test. Mol Phylogenet Evol 17:401-406.

Farris JS (1966) Estimation of conservatism of characters by constancy within biological populations. Evolution 20:587-591.

Farris JS, Källersjö M, Kluge AG, Bult C (1995) Testing significance of incongruence. Cladistics 10:315-319.

Felsenstein J (1985) Confidence limits on phylogenies: an approach using the bootstrap. Evolution 39:783-791.

Fouquet A, Blotto BL, Maronna MM, Verdade VK, Juncá FA, de Sá R, Rodrigues MT (2013) Unexpected phylogenetic positions of the genera Rupirana and Crossodactylodes reveal insights into the biogeography and reproductive evolution of leptodactylid frogs. Mol Phylogenet Evol 67:445-457.

Frost DR (2014) Amphibians Species of the World: An Online Reference. Version 6.0 (January 21th, 2014). American Museum of Natural History, New York. Electronic Database accessible at http:// research.amnh.org/vz/herpetology/amphibia/.

Frost DR, Grant T, Faivovich J, Bain RH, Haas A, Haddad CFB, de Sá RO, Channing A, Wilkinson M, Donellan SC, Raxworthy CJ, Campbell JA, Blotto BL, Moler P, Drewes RC, Nussbaum RA, Lynch JD, Green DM, Wheeler WC (2006) The Amphibian Tree of Life. B Am Mus Nat Hist 297:1-370.

Gatesy J, O’Grady P, Baker RH (1999) Corroboration among data sets in simultaneous analysis: hidden support for phylogenetic relationships among higher level artiodactyl taxa. Cladistics 15:271-313.

Goloboff P (1993) Estimating character weights during tree search. Cladistics 9:83-91.

Goloboff P (1995) Parsimony and weighting: a reply to Turner and Zandee. Cladistics 11:91-104.

Goloboff P, Farris J, Nixon K (2003) T.N.T. tree analysis using new technology. Program and documentation available from the authors in http://www.zmuc.dk/public/phylogeny.

Gosner KL (1960) A simplified table for staging anuran embryos and larvae with notes on identification. Herpetologica 16:183-190.

Grant T, Kluge AG (2003) Data exploration in phylogenetic inference: scientific, heuristic, or neither. Cladistics 19:379-418.

Grant T, Frost DR, Caldwell JP, Gagliardo R, Haddad CFB, Kok PJR, Brucemeans D, Noonan BP, Schargel WE, Wheeler WC (2006)
Phylogenetics systematics of dart-poison frogs and their relatives (Amphibia: Athesphatanura: Dendrobatidae). B Am Mus Nat Hist 299:1-262

Griffiths I (1963) The phylogeny of the Salientia. Biol Rev 38:241-292.

Griffiths I, de Carvalho AL (1965) On the validity of employing larval characters as major phyletic indices in Amphibia, Salientia. R Bras Biol 25:113-121.

Haas A (2003) Phylogeny of frogs as inferred from primarily larval characters (Amphibia, Anura). Cladistics 19:23-89.

Hero JM, Galatti U (1990) Characteristics distinguishing Leptodactylus pentadactylus and L. knudseni in the central amazon rainforest. J Herpetol 24:227-228.

Heyer WR (1969) The adaptive ecology of the species group of the genus Leptodactylus (Amphibia, Leptodactylidae). Evolution 23:421-428.

Heyer WR (1970) Studies on the frogs of the genus Leptodactylus (Amphibia: Leptodactylidae). VI. Biosystematics of the melanonotus group. Contrib Sci Natur Hist Mus Los Angeles County 191:1-48.

Heyer WR (1973) Systematics of the marmoratus group of the genus Leptodactylus (Amphibia, Leptodactylidae). Contrib Sci Natur Hist Mus Los Angeles County 251:1-50.

Heyer WR (1974) Relationships of the marmoratus species group (Amphibia, Leptodactylidae) within the subfamily Leptodactylinae. Contrib Sci Natur Hist Mus Los Angeles County 253:1-46.

Heyer WR (1978) Systematics of the fuscus group of the frog genus Leptodactylus (Amphibia: Leptodactylidae). Sci Bull Nat Hist Mus Los Angeles 29:1-85.

Heyer WR (1979) Systematics of pentadactylus species group of the frog genus Leptodactylus (Amphibia: Leptodactylidae). Smithson Contr Zool 301:1-43.

Heyer WR (1998) The relationships of Leptodactylus diedrus (Anura, Leptodactylidae). Alytes 16:1-24.

Heyer WR (2005) Variation and taxonomic clarification of the large species of the Leptodactylus pentadactylus species group (Amphibia: Leptodactylidae) from Middle America, Northern South America, and Amazonia. Arq Zool 37:269-348.

Heyer WR, Pyburn WF (1983) Leptodactylus riveroi, a new frog species from Amazonia, South America (Anura: Leptodactylidae). P Biol Soc Wash 96:560-566.

Hillis DM, Bull JJ (1993) An empirical test of bootstrapping as a method for assessing confidence in phylogenetic analysis. Syst Biol 42: $182-192$.

Hillis DM, Wiens JJ (2000) Molecular versus morphology systematics: conflicts, artefacts, and misconceptions. In: Wiens JJ (ed.), Phylogenetic Analysis of Morphological Data. Smithsonian Institution Press, Washington, DC, pp 1-19.

Kluge AG (1997) Testability and the refutation and corroboration of cladistics hypotheses. Cladistics 13:81-96.

Kluge AG, Farris JS (1969) Quantitative phyletics and the evolution of anurans. Syst Zool 18:1-32.

Langone JA, de Sá RO (2005) Redescripción de la morfologia larval externa de dos espécies del grupo de Leptodactylus fuscus (Anura, Leptodactylidae). Phyllomedusa 6:45-60.

Larson PM, de Sá RO (1998) Larval cranial morphology of Leptodactylus larvae (Leptodactylidae: Leptodactylinae): its utility in phylogenetic reconstruction. J Morphol 238:287-305.

Lataste F (1879) Étude sur le Discoglosse. Actes Soc Linn Bordeaux 33:275-341.

Lavilla EO, Fabrezi M (1992) Anatomía craneal de larvas de Lepidobatrachus llanensis y Ceratophrys cranwelli (Anura: Leptodactylidae). Acta Zool Lilloana XLII1:5-11.

Maddison WP, Maddison DR (1992) McClade: Analysis of Phylogeny and Character Evolution, Version 4.02. Sinauer Associates Inc., Sunderland, MA.

Maddison WP, Maddison DR (2009) Mesquite: a modular system for evolutionary analysis, Version 2.71. Accessible at http://mesquiteproject. org.

Maglia AM, Pugener LA, Trueb L (2001) Comparative developmet of anurans: using phylogeny to understand ontogeny. Am Zool 41:538551.

Miranda NEO, Ferreira A (2008) Morfologia bucal interna dos girinos de Leptodactylus labyrinthicus Spix, 1824 (Amphibia: Anura: Leptodactylidae). Biota Neotrop 8:225-230. 
Miranda NEO, Ferreira A (2009) Morfologia oral interna de larvas dos gêneros Eupemphix, Physalaemus e Leptodactylus (Amphibia: Anura). Biota Neotrop 9:165-176.

Müller KF (2005) The efficiency of different search strategies in estimating parsimony jackknife, bootstrap, and Bremer support. BMC Evol Biol 5:58-67.

Noble GK (1926) The importance of larval characters in the classification of South African Salientia. Am Mus Novit 237:1-17.

Orton GL (1953) The systematics of vertebrate larvae. Syst Zool 2:6375.

Orton GL (1957) The bearing of larval evolution on some problems in frog classification. Syst Zool 6:79-86.

Peña C, Wahlberg N, Weingartner E, Kodandaramaiah U, Nylin S, Freitas AVL, Brower AVZ (2006) Higher level phylogeny of Satyrinae butterflies (Lepidoptera: Nymphalidae) based on DNA sequence data. Mol Phylogenet Evol 40:29-49.

Ponssa ML (2008) Cladistics analysis and osteological descriptions of the frogs species in the Leptodactylus fuscus group (Anura, Leptodactylidae). J Zool Syst Evol Res 46:249-266.

Prado VHM (2006) Similaridade ecológica em comunidades de girinos (Amphibia, Anura): o papel dos components históricos (filogenéticos) e contemporâneos (ecológicos). Unpublished master thesis, Instituto de Biociências, Letras e Ciências Exatas da Universidade Estadual Paulista Júlio de Mesquita Filho (UNESP), 151 pp.

Prado CPA, Toledo LF, Zina J, Haddad CFB (2005) Trophic eggs in the foam nests of Leptodactylus labyrinthicus (Anura, Leptodactylidae): and experimental approach. Herpetol J 15:279-284.

Pugener LA, Maglia AM, Trueb L (2003) Revisiting the contribution of larval characters to an analysis of phylogenetic relationships of basal anurans. Zool J Linn Soc 139:129-155.

Pyron RA, Wiens JJ (2011) A large-scale phylogeny of Amphibia including over 2800 species, and a revised classification of advanced frogs, salamanders, and caecilians. Mol Phylogenet Evol 61:543-583.

Ramón Formas J, Brieva L (2004) The tadpoles of Alsodes vanzolinii and A. verrucosus (Anura: Leptodactylidae) with descriptions of their internal oral and larval cranial morphology. Amphibia-Reptilia 25:151164.

Ruvinsky I, Maxson LR (1996) Phylogenetic relationships among bufonoid frogs (Anura: Neobatrachia) inferred from mitochondrial DNA sequences. Mol Phylogenet Evol 5:533-547.

de Sá RO, Brandão R, Dall'ara Guimarães L (2007a) Description of the tadpole of Leptodactylus pustulatus Peters, 1870 (Anura: Leptodactylidae). Zootaxa 1523:49-58.

de Sá RO, Langone JA, Segalla MV (2007b) The tadpole of Leptodactylus notoaktites Heyer, 1978 (Anura, Leptodactylidae). SAJH 2:69-75.

Silva WR, Giaretta AA, Facure KG (2005) On the natural history of the South America pepper frog, Leptodactylus labyrinthicus (Spix, 1824) (Anura: Leptodactylidae). J Nat Hist 39:555-566.

Sokol OM (1975) The phylogeny of anuran larvae: a new look. Copeia 1975:1-23.

Song J, Parenti LR (1995) Clearing and staining whole fish specimens for simultaneous demonstrations of bone, cartilage, and nerves. Copeia 1995: $114-118$

Swofford DL (1998) PAUP*: Phylogenetic Analyses Using Parsimony (*and Other Methods), Version 4. Sinauer Associates, Sunderland, MA.
Turner H, Zandee R (1995) The behaviour of Goloboff's tree fitness measure F. Cladistics 11:57-72.

Vera Candioti MF (2005) Morphology and feeding in tadpoles of Ceratophrys cranwelli (Anura: Leptodactylidae). Acta Zool-Stockholm 86:1-11.

Vera Candioti MF (2008) Larval anatomy of Andean tadpole of Telmatobius (Anura: Ceratophryidae) from northwestern Argentina. Zootaxa 1938:40-60.

Vera Candioti MF, Brusquetti F, Netto F (2007) Morphological characterization of Leptodactylus elenae tadpoles (Anura: Leptodactylidae: L. fuscus group), from central Paraguay. Zootaxa 1435:1-17.

Vieira WLS, Santana GG, Vieira KS (2007) Description of the tadpole of Leptodactylus vastus (Anura: Leptodactylidae). Zootaxa 1529:6168

Wassersug RJ (1976) Oral morphology of anuran larvae: terminology and general description. Occ Pap Mus Nat Hist Univ Kansas 48:1-23.

Wassersug RJ (1980) Internal oral features of larvae from eight anuran families: functional, systematic, evolutionary and ecological considerations. Misc publ Univ Kans Mus Nat Hist 68:1-146.

Wassersug RJ, Heyer WR (1988) A survey of internal oral features of Leptodactyloid larvae (Amphibia: Anura). Smithson Contrib Zool 457:1-99.

Weber LN, Caramschi U (2006) Descrição da morfologia oral interna de larvas do gênero Crossodactylus Duméril \& Bibron, 1841 (Amphibia, Anura, Leptodactylidae). Arq Mus Nac 64:141-149.

Wiens JJ (1995) Polymorphic characters in phylogenetic systematics. Syst Biol 44:482-550.

Wiens JJ (2000) Coding morphological variation within species and higher tax for phylogenetic analysis. In: Wiens JJ (ed.), Phylogenetic Analysis of Morphological Data. Smithsonian Institution Press, Washington, DC and London, pp 115-145.

Wynn A, Heyer WR (2001) Do geographically widespread species of tropical amphibians exist? An estimated of genetic relatedness within the neotropical frog Leptodactylus fuscus (Schneider 1799) (Anura: Leptodacytilidae). Trop Zool 14:255-285.

\section{Supporting Information}

Additional Supporting Information may be found in the online version of this article:

Table S1. Species, locality, acronym and collection number, and tadpoles analysed.

Table S2. List of characters and character states of the internal buccal morphology used in this study.

Table S3. List of characters and character states of the larval cranial morphology used in this study.

Data S1. Combined matrix used this study.

Data S2. Matrix representing 84 larval characters and 27 taxa.

Data S3. Four most parcimonious cladograms from the maximum parsimony analysis of 84 larval characters.

Data S4. Twenty-five most parcimonious cladograms from the maximum parsimony analysis of data of adult specimens and larval characters. 